\title{
ARTICLE \\ Growth and physiological responses of creeping bentgrass (Agrostis stolonifera) to elevated carbon dioxide concentrations
}

\author{
Patrick Burgess and Bingru Huang
}

The atmospheric carbon dioxide level has increased and is predicted to continue increasing, which may affect various aspects of plant growth. The objective of this study was to investigate the effects of doubling the carbon dioxide level on the growth and physiological activities of a widely utilized cool-season turfgrass species, creeping bentgrass (Agrostis stolonifera L. 'Penncross'). 'Penncross' plants were established in fritted clay medium and maintained under well-irrigated and well-fertilized conditions in growth chambers. The plants were exposed to either ambient carbon dioxide concentrations $\left(400 \pm 10 \mu \mathrm{mol} \mathrm{L} \mathrm{L}^{-1}\right.$ ) or elevated carbon dioxide concentrations $\left(800 \pm 10 \mu \mathrm{mol} \mathrm{L}{ }^{-1}\right)$ for 12 weeks. Plants grown under elevated carbon dioxide displayed a significantly faster growth rate of their lateral stems (stolons) and increased shoot and root dry weight but a reduced specific leaf area compared to those plants at ambient carbon dioxide levels. Fast stolon growth is a highly desirable trait for turfgrass establishment and recovery from physical damage. The root length and surface area were also increased due to the elevated $\mathrm{CO}_{2}$, which may facilitate water uptake and serve critical drought-avoidance roles when irrigation water is limited. Elevated carbon dioxide caused an increase in the leaf net photosynthetic rate but a reduction in the stomatal conductance and transpiration rate, contributing to improved water use efficiency in creeping bentgrass. Efficient water use is especially important for turfgrass plant survival when irrigation water is limited. Our results suggested that cool-season turfgrass species may greatly benefit from increasingly elevated carbon dioxide concentrations via growth promotion and increasing water use efficiency.

Horticulture Research (2014) 1, 14021; doi:10.1038/hortres.2014.21; Published online: 30 April 2014

\section{INTRODUCTION}

Atmospheric carbon dioxide $\left(\mathrm{CO}_{2}\right)$ levels have risen by $69 \mu \mathrm{mol} \mathrm{L}^{-1}$ from 1958 to $2008,{ }^{1}$ and the rate of increase is predicted to hasten during the next century. ${ }^{2}$ Elevated $\mathrm{CO}_{2}$ concentrations have a significant impact on plant growth, productivity and species composition in agricultural and natural ecosystems. ${ }^{3}$ Meta-analysis of wild grass species has shown that C3 grasses have increased rates of lateral tillering when exposed to elevated $\mathrm{CO}_{2}$, while $\mathrm{C} 4$ grasses display a greater increase in leaf area. ${ }^{4}$ The positive effects of elevated $\mathrm{CO}_{2}$ on annual crops are linked to increased photosynthesis and water use efficiency, ${ }^{5-7}$ as well as root formation and root elongation, ${ }^{3,8}$ associated with enhanced cell wall extensibility and carbon supply under elevated $\mathrm{CO}_{2} \cdot{ }^{9}$ A majority of the research regarding plant response to elevated $\mathrm{CO}_{2}$ has been focused on agronomic crop species, which themselves vary in growth, productivity and response to interacting environmental stresses. ${ }^{3}$ Few studies have investigated the effects of elevated $\mathrm{CO}_{2}$ on perennial grasses utilized as fine turfgrass. ${ }^{10-12}$ There are over $35000 \mathrm{~km}^{2}$ of managed turfgrass within the United States, ${ }^{13}$ where it serves many important environmental functions, such as erosion control, surface water detoxification and the control of allergens and diseases. ${ }^{14}$ Hence, changes in turfgrass growth, physiology and stress-response due to rising $\mathrm{CO}_{2}$ levels are of great importance for many aspects of environmental stewardship and turfgrass management.

Unlike other agronomic or horticultural crops that are grown for grain or fruit yield production, the goal of turfgrass management is to obtain high quality plants as defined by leaf color, canopy density, aesthetics and playability, and the consistency of these traits over time. ${ }^{15}$ To achieve high quality, turfgrasses are managed to maintain active yet slow vegetative growth rates and high water use efficiency, which becomes especially important when water for irrigation is limited. As human populations grow and climate patterns (notably atmospheric $\mathrm{CO}_{2}$ levels) continue to change, there is an ever-increasing demand for the efficient allocation of water resources, justified through the research of turfgrass water use patterns responding to environmental conditions. ${ }^{16}$ Understanding how elevated $\mathrm{CO}_{2}$ may affect the major traits of turfgrass growth and water use efficiency provides guidelines for how to develop efficient management tactics, such as irrigation, to maintain quality turfgrass in the scenario of increasing $\mathrm{CO}_{2}$ concentration in the future.

The objective for this research was to examine the effects of a doubled $\mathrm{CO}_{2}$ concentration on growth, morphological, and physiological processes for cool-season creeping bentgrass maintained under well-watered and well-fertilized conditions.

\section{MATERIALS AND METHODS}

Plant material and growth conditions

Individual tillers (40 per pot) of creeping bentgrass (Agrostis stolonifera $\mathrm{L}$. 'Penncross') were propagated in plastic pots (10 cm diameter $\times 40 \mathrm{~cm}$ depth) filled with fritted clay medium. The plants were maintained in a greenhouse with an average temperature of $22 / 17{ }^{\circ} \mathrm{C}$ (day/night), $700 \mu \mathrm{mol} \mathrm{m}{ }^{-2} \mathrm{~s}^{-1}$ photosynthetic active radiation from natural sunlight, and $65 \%$ relative humidity for 56 days to establish canopy and root systems. During establishment, the plants were irrigated to water-holding capacity daily, fertilized with half-strength Hoagland's solution ${ }^{17}$ twice per week and had their leaves trimmed once per week to maintain a 5-cm canopy height. The plants were then trimmed to a 2-cm canopy height and moved to controlled-climate growth chambers (Environmental Growth Chamber, Chargrin Falls, $\mathrm{OH}$, USA) set to $21 / 18{ }^{\circ} \mathrm{C}$ (day/night) temperature, $60 \%$ relative humidity, $650 \mu \mathrm{mol} \mathrm{m} \mathrm{m}^{-2} \mathrm{~s}^{-1}$ photosynthetic active radiation and a 14-h photoperiod 
for 1 week prior to $\mathrm{CO}_{2}$ treatment. During the 12-week $\mathrm{CO}_{2}$ treatment, the plants were maintained under well-watered conditions with daily irrigation and fertilized with half-strength Hoagland's solution ${ }^{17}$ twice per week, and their leaves were not trimmed.

\section{Treatments and experimental design}

Plants were exposed to two $\mathrm{CO}_{2}$ treatments: ambient concentration $\left(400 \pm 10 \mu \mathrm{mol} \mathrm{L}^{-1}\right)$ or elevated concentration $\left(800 \pm 10 \mu \mathrm{mol} \mathrm{L}^{-1}\right)$. Each $\mathrm{CO}_{2}$ treatment was applied in four different growth chambers, and the plants were moved between the chambers every 3 days to eliminate the potential confounding effects of environmental variations between chambers. The experiment was arranged in a randomized complete block design with four replicates (pots) per treatment.

The ambient and elevated $\mathrm{CO}_{2}$ concentrations within the chambers were maintained through an automatic $\mathrm{CO}_{2}$ controlling system connected to the $\mathrm{CO}_{2}$ source-tank containing $100 \%$ research-grade $\mathrm{CO}_{2}$ using a previouslydescribed method. ${ }^{10}$ The $\mathrm{CO}_{2}$ concentrations inside the chambers were continuously monitored using an infrared gas analyzer (Li-820; LICOR, Inc., Lincoln, NB, USA) connected to a computer data logger. The $\mathrm{CO}_{2}$ concentration was maintained using an automatic controlling system consisting of a programmable logic controller unit, solenoid valves and a laptop computer with software capable of monitoring and maintaining the $\mathrm{CO}_{2}$ concentration within $10 \mu \mathrm{mol} \mathrm{L}{ }^{-1}$ of the ambient or elevated target levels.

\section{Morphological analysis}

The lengths of the lateral stems (stolons) were measured at 70 and 84 days of $\mathrm{CO}_{2}$ treatment from 10 randomly-selected stolons per replicate, and the values were averaged together within each replicate. The specific leaf area was measured at $63,70,77$ and 84 days of $\mathrm{CO}_{2}$ treatment. Twenty of the second fully expanded leaves per replicate were excised from atop the stolons and were immediately scanned using a hand-held digital scanner. The leaves were then dried in an oven set to $80^{\circ} \mathrm{C}$ for 7 days, and their dry weight was subsequently measured. The leaf area was calculated with Digimizer software (MedCalc Software bvba, Mariakerke, Belgium) using scanned digital images of the fresh leaf samples. The specific leaf area was then expressed as the leaf area per unit dry weight leaf tissue. The number of stomates per unit leaf area was measured at $63,70,77$ and 84 days of $\mathrm{CO}_{2}$ treatment. Twenty of the second fully expanded leaves were detached from atop stolons and placed on a glass slide in immersion oil to maintain the original state of the stomates. Images ( $1344 \times 1024$ pixels) of the adaxial leaf surface were captured under a light microscope (NIKON Inc., Melville, NY, USA) equipped with a digital camera. The camera was calibrated prior to usage for the accurate conversion of pixel size to actual leaf area. All plants were destructively sampled at 84 days of $\mathrm{CO}_{2}$ treatment for an analysis of the root and shoot biomass accumulation. The roots were severed from the shoots at the soil line and washed free of fritted clay medium. A subset of the root tissue was divided into four zones (0-10, $10-20,20-30$ and $30-40 \mathrm{~cm}$ ), stained in $1 \%$ crystal violet solution and scanned with a digital scanner to generate the root images. The images were then analyzed with WinRHIZO Basic V.2002 software (Regent Instruments Inc., Quebec City, Que., Canada) for their root length and surface area. All of the tissue was then dried in an oven at $80{ }^{\circ} \mathrm{C}$ for 7 days, and the dry weight was subsequently measured, yielding the shoot weight, root weight and root to shoot ratio $(\mathrm{R} / \mathrm{S})$.

\section{Physiological analysis}

The leaf net photosynthetic rate (Pn), stomatal conductance (gs) and transpiration rate $(T)$ were measured at $63,70,77$ and 84 days of treatment. Six of the second fully expanded leaves from atop stolons were arranged in a $6 \mathrm{~cm}^{2}$ cuvette chamber attached to a portable infrared gas analyzer (Li6400; LICOR, Inc.). The leaf Pn, gs and T were measured in the leaf chamber using a red and blue light source at $800 \mu$ mol photon $\mathrm{m}^{-2} \mathrm{~s}^{-1}$ and a flow rate of $500 \mu \mathrm{mol} \mathrm{s}{ }^{-1}$. The leaf area was determined using a hand-held digital scanner immediately following leaf removal from the cuvette. Water use efficiency (WUE) was also measured at 63, 70, 77 and 84 days of $\mathrm{CO}_{2}$ treatment according to the formula $\mathrm{WUE}=\mathrm{Pn} / \mathrm{T}$.

\section{Statistical analysis}

The main effects of the $\mathrm{CO}_{2}$ treatment were determined by an analysis of variance according to the general linear model procedure of SAS (version 9.2; SAS Institute, Cary, NC, USA). Differences between the treatment mean values were distinguished by Fisher's protected least significance difference (LSD) test at the 0.05 probability level.

\section{RESULTS AND DISCUSSION}

Shoot and root growth of creeping bentgrass as affected by elevated carbon dioxide concentrations

Creeping bentgrass plants grown under elevated $\mathrm{CO}_{2}$ had significantly longer stolons at 70 and 84 days of $\mathrm{CO}_{2}$ treatment compared to the control plants maintained under ambient $\mathrm{CO}_{2}$ (Figure 1a). Elevated $\mathrm{CO}_{2}$ increased the stolon length by approximately $25 \%$ at 70 days of $\mathrm{CO}_{2}$ treatment. The treatment effects became more pronounced over time; the stolon length increased by $40 \%$ due to elevated $\mathrm{CO}_{2}$ at 84 days of $\mathrm{CO}_{2}$ treatment. $\mathrm{A}$ visual depiction showing the growth differences between the elevated and ambient $\mathrm{CO}_{2}$ treatments just prior to plant harvest is provided in Figure $1 \mathrm{~b}$. Increased rates of lateral spread through stolon growth is a highly desirable turfgrass trait and serves to improve aesthetics, functionality, and recovery from stress damage. ${ }^{18}$ The promotion of lateral spread through elevated $\mathrm{CO}_{2}$ may offset the need for other supplemental management tactics, including inorganic nutrient fertilization, to promote stand density or recovery from stress, as well as for turfgrass establishment from seeds or sprigs. Plant hormones such as gibberellic acid serve roles in cell and stem elongation, ${ }^{19}$ but

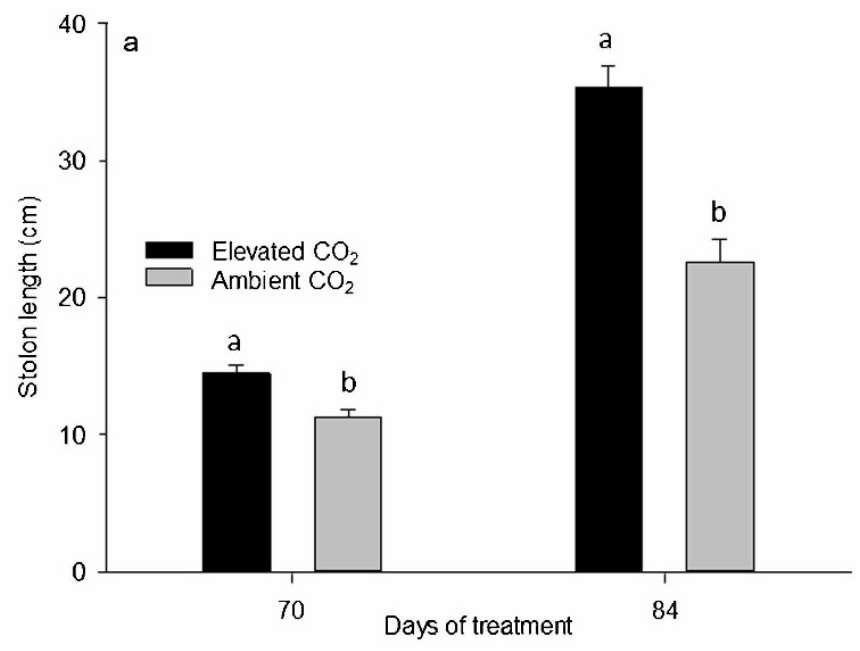

b

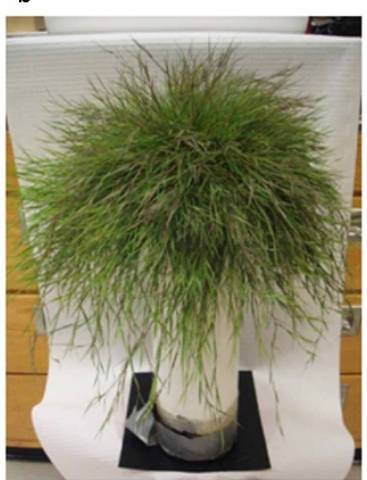

Elevated $\mathrm{CO}_{2}$

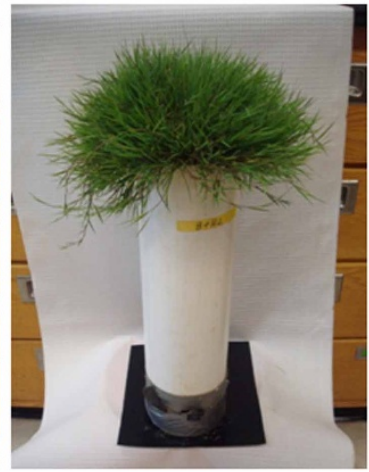

Ambient $\mathrm{CO}_{2}$
Figure 1. Stolon lengths (a) at 70 and 84 days of elevated carbon dioxide treatment. Different letters atop bars indicate significant differences $(p \leqslant 0.05)$ between treatments on a given sampling day. Photos (b) of creeping bentgrass plants at 84 days of treatment with elevated or ambient $\mathrm{CO}_{2}$ concentrations. 
whether stolon elongation affected by elevated $\mathrm{CO}_{2}$ is related to the changes in hormone concentration or balance is unknown. The underlying mechanisms of stolon elongation in creeping bentgrass as stimulated by $\mathrm{CO}_{2}$ deserve further investigation.

The specific leaf area, expressed as the leaf area per unit dry weight, is one of the most widely used traits for describing leaf characteristics. ${ }^{20}$ Specific leaf area in creeping bentgrass was significantly reduced due to the elevated $\mathrm{CO}_{2}$ from 63 to 84 days of treatment (Figure 2a). During any of the four sampling days, there was a $22 \%-25 \%$ reduction in the specific leaf area for plants grown under elevated $\mathrm{CO}_{2}$ compared to those grown under ambient $\mathrm{CO}_{2}$. In addition, leaves developed under elevated $\mathrm{CO}_{2}$ were shorter than those formed under ambient $\mathrm{CO}_{2}$ (Figure 2b). The combination of shorter leaves and a lower specific leaf area indicated that plants developed under elevated $\mathrm{CO}_{2}$ had a smaller leaf area per unit biomass or the leaves became smaller and thicker. Smaller leaves are highly desirable in turfgrass because they require less clipping accumulation and require a lower mowing frequency. ${ }^{21}$ It was shown that poplar (Populus trichocarpa) grown in elevated $\mathrm{CO}_{2}$ had thicker leaves and a greater leaf weight per unit leaf area. ${ }^{22}$ It was suggested that the thicker leaves with increased mesophyll cells of poplar plants may be a reason for the observed increase or maintenance of photosynthetic rates. A review summarized the results for the cellular expansion, division and patterning of plant species grown under elevated $\mathrm{CO}_{2}$ and showed that increased leaf thickness due to cell expansion is a common $\mathrm{CO}_{2}$-induced response for many plant types. ${ }^{8}$ Leaf thickness has also been shown to have an inverse relationship with the transpiration rate wherein thicker
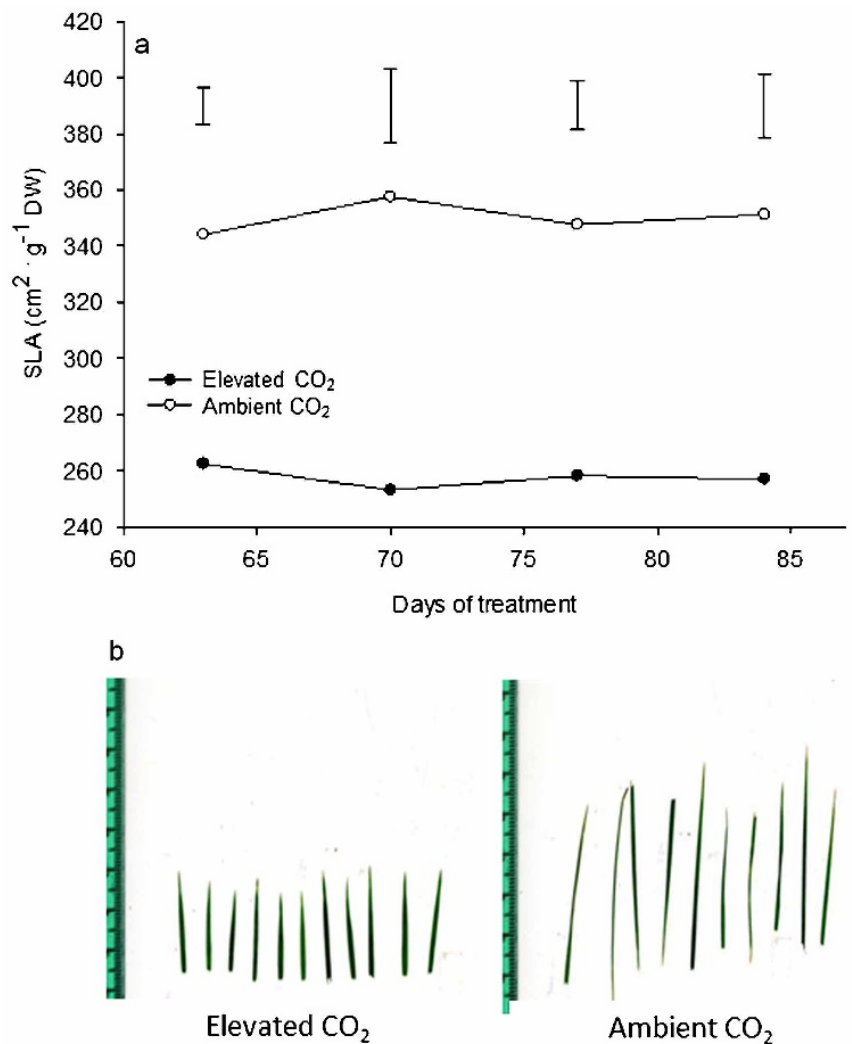

Figure 2. Specific leaf areas (a) at $63,70,77$ and 84 days of elevated carbon dioxide treatment. Vertical bars indicate LSD values $(p \leqslant 0.05)$ for comparison between treatments at a given day of treatment where significant differences were detected. Photos (b) of creeping bentgrass leaves at 84 days of treatment with elevated or ambient $\mathrm{CO}_{2}$ concentrations. leaves have greater transpiration efficiency. ${ }^{23}$ Therefore, smaller and thicker leaves due to elevated $\mathrm{CO}_{2}$ may promote drought tolerance in cool-season turfgrass by slowing the transpirational water loss and prolonging plant survival when water for irrigation is limited.

The shoot biomass was approximately $35 \%$ greater for creeping bentgrass plants grown under elevated $\mathrm{CO}_{2}$ compared to plants maintained under ambient $\mathrm{CO}_{2}$, while the root biomass increased by $37 \%$ due to elevated $\mathrm{CO}_{2}$ (Figure 3a). The increased shoot biomass in creeping bentgrass was mainly due to enhanced growth of the lateral stems, as discussed above. An early review described the effects of doubling the $\mathrm{CO}_{2}$ concentration on 37 different plant species, including agricultural crops, herbaceous species and woody ornamentals, and concluded that the doubled $\mathrm{CO}_{2}$ levels increased the grain and vegetative yield by an average of $33 \%$ compared to ambient controls. ${ }^{24} \mathrm{~A}$ more recent review of soybean (Glycine max) research showed that the vegetative biomass and harvest yield increased by $37 \%$ and $18 \%$, respectively, for plants grown under elevated $\mathrm{CO}_{2}$ compared to plants under ambient $\mathrm{CO}_{2}$ conditions. ${ }^{25}$ It was shown that doubling the $\mathrm{CO}_{2}$ concentration will increase the shoot dry weight two-fold for colonial bentgrass (Agrostis capillaris) after 79 days of treatment, while a similar but slower response was noted after 189 days for sheep fescue (Festuca vivipara). ${ }^{26} \mathrm{~A}$ higher shoot biomass or increased number of shoots
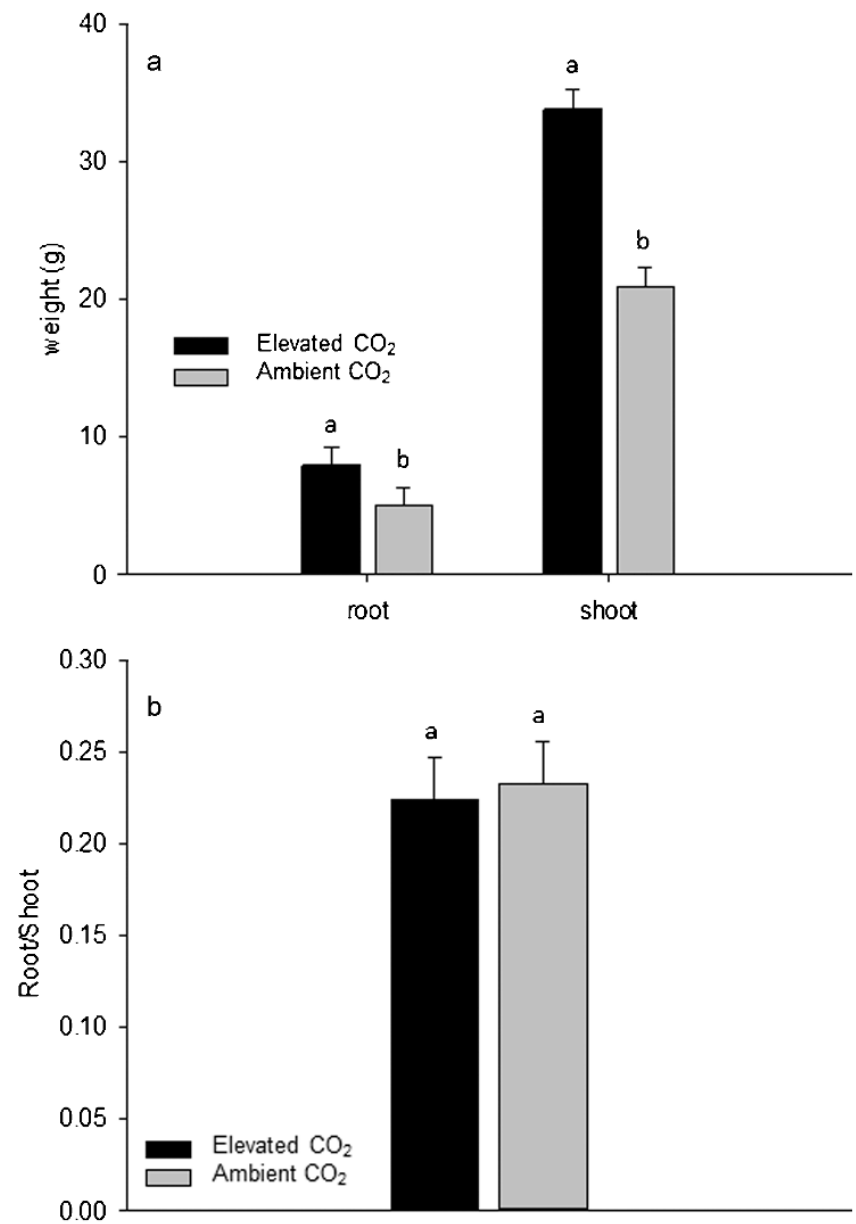

Figure 3. Root and shoot dry weights (a) and root to shoot ratios (b) after 84 days of elevated carbon dioxide treatment. Different letters atop bars indicate significant differences $(p \leqslant 0.05)$ between treatments on a given sampling day. 

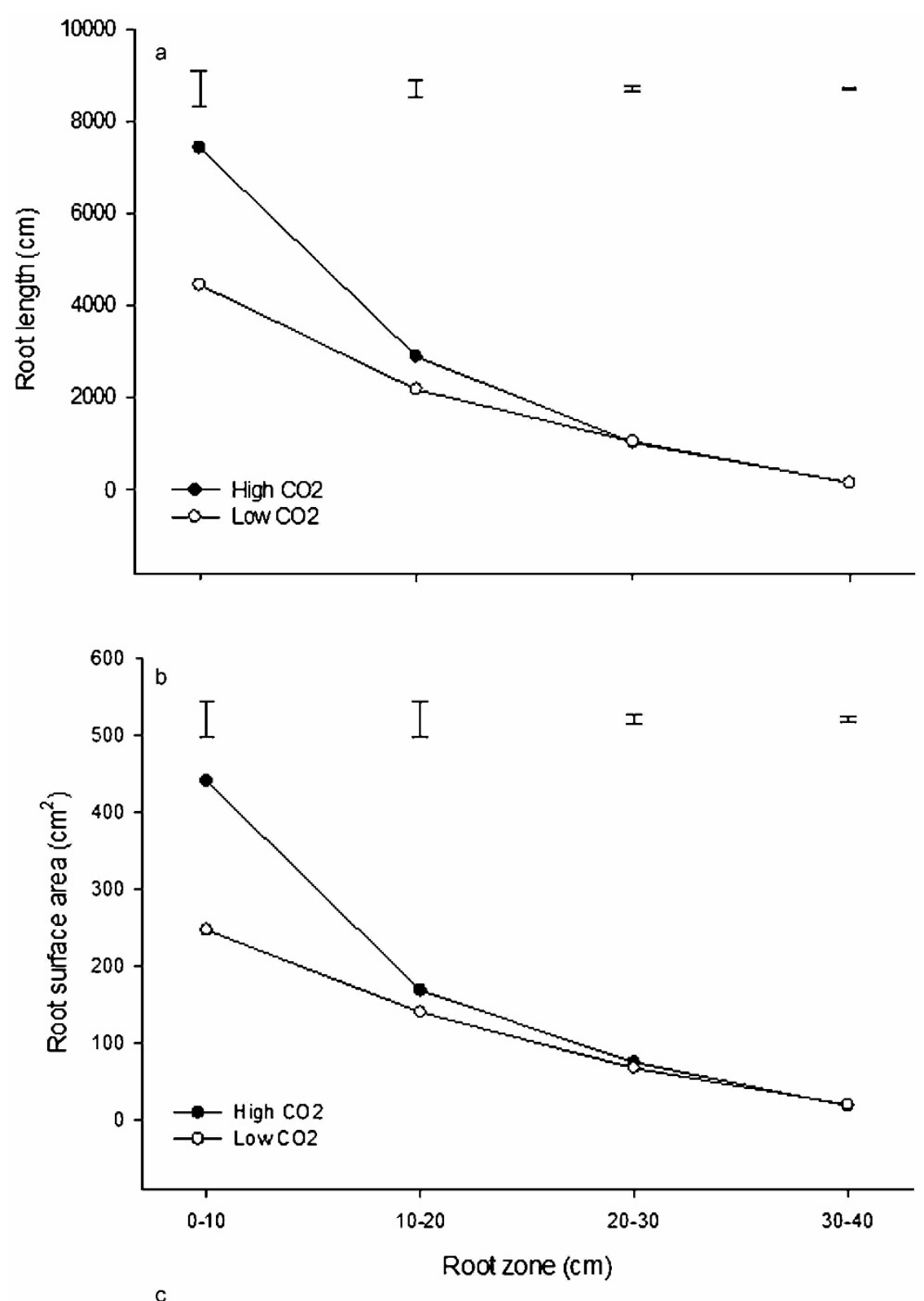

c
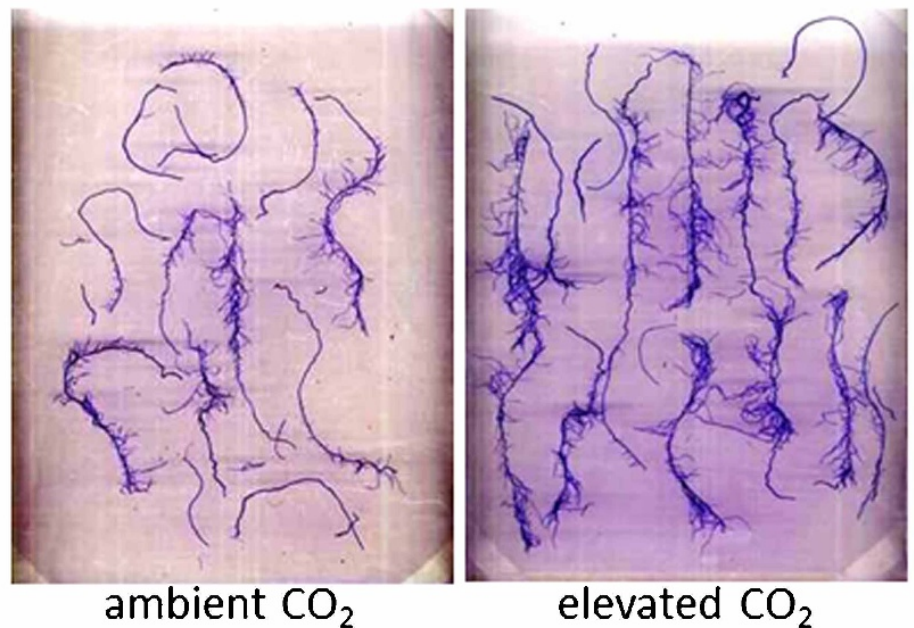

Figure 4. Root lengths (a) and surface areas (b) in the 0-10, 10-20, 20-30 and 30-40 cm root zones for elevated and ambient carbon dioxide treatments. Different letters atop bars indicate significant differences $(p \leqslant 0.05)$ between treatments. Photos (c) of stained creeping bentgrass root subsets in the $0-10 \mathrm{~cm}$ zone after 84 days of treatment with elevated or ambient $\mathrm{CO}_{2}$ concentrations. 
per plant will promote the canopy density and improve the overall functionality and aesthetics of the turfgrass stand. ${ }^{27}$

The root biomass typically increases in C3, C4 and CAM plants growing in elevated $\mathrm{CO}_{2}$ environments, but the degree of change relative to ambient controls is highly dependent upon the plant species and other interacting factors, such as drought stress and nutrient availability. ${ }^{3}$ It was reported that the root biomass of a tallgrass prairie mixture composed of big bluestem (Andropogon gerardii), little bluestem (A. scoparius), Indian grass (Sorghastrum nutans) and Kentucky bluegrass (Poa pratensis) increased by $55 \%$ from 120 to $270 \mathrm{~g} \mathrm{~m}^{-2}$ for ambient versus elevated $\mathrm{CO}_{2}$ conditions. ${ }^{28}$ However, as these grasses were grown as a mixture, it was impossible to delineate which species (C3 versus $\mathrm{C4}$ ) contributed most to the observed increase in roots, a topic that deserves further consideration in future studies. Another study that investigated the effects of elevated $\mathrm{CO}_{2}$ for two contrasting grassland swards dominated by either sheep fescue (Festuca ovina) alone or a combination of matgrass (Nardus stricta) and heath rush (Juncus squarrosus) reported a $40 \%-50 \%$ increase in the root biomass for either system under elevated $\mathrm{CO}_{2} \cdot{ }^{29}$ Reports of $\mathrm{R} / \mathrm{S}$ responding to changes in $\mathrm{CO}_{2}$ concentrations are conflicting and vary across different plant species with both increases and decreases to R/S previously reported. ${ }^{30,31}$ In this study, the root to shoot ratio (R/S) of creeping bentgrass did not change with $\mathrm{CO}_{2}$ treatment (Figure $3 \mathrm{~b}$ ), suggesting that shoot and root growth was maintained in balance even with elevated $\mathrm{CO}_{2}$ for creeping bentgrass.

The enhanced total root biomass in creeping bentgrass was due to increases in the total root length and surface areas, particularly in upper soil profiles under elevated $\mathrm{CO}_{2}$. Creeping bentgrass plants grown under elevated $\mathrm{CO}_{2}$ had significantly greater root length in the upper $0-10 \mathrm{~cm}$ and middle $10-20 \mathrm{~cm}$ root zones, but there were no differences in root length in the $20-30$ or $30-40 \mathrm{~cm}$ root zones (Figure $4 \mathrm{a}$ ). Similarly, the greatest effects of elevated $\mathrm{CO}_{2}$ on the creeping bentgrass root surface area were observed in the uppermost $0-10 \mathrm{~cm}$ zone, whereas no significant differences occurred in the lower root zones (Figure 4b). A visual depiction of stained root subsets in the upper $0-10 \mathrm{~cm}$ zone between elevated and ambient $\mathrm{CO}_{2}$ treatment is provided in Figure 4c. A review described the effects of elevated $\mathrm{CO}_{2}$ on plant root systems and reported that both the root length and root number are significantly increased due to elevated $\mathrm{CO}_{2}$ across $\mathrm{C} 3$ and $\mathrm{C} 4$ species. ${ }^{32}$ In this comprehensive review, it was also reported that other structural aspects of root growth tend to increase when plants are maintained at elevated $\mathrm{CO}_{2}$ levels, including the volume, branching and relative growth rate, whereas reports of changes to the root surface area due to $\mathrm{CO}_{2}$ level are lacking. Root proliferation through increased length or surface area serves critical drought-avoidance functions for water uptake ${ }^{33}$ and has been implicated in prolonging turfgrass survival during periods of drought stress. ${ }^{34,35}$ The extent to which elevated $\mathrm{CO}_{2}$ may promote the drought tolerance of creeping bentgrass plants through changes to root structure deserves further consideration.

Photosynthesis, transpiration, water use efficiency and stomatal density of creeping bentgrass as affected by elevated carbon dioxide concentrations

The net photosynthetic rate of single leaves $(\mathrm{Pn})$ was significantly higher for creeping bentgrass plants grown under elevated $\mathrm{CO}_{2}$ compared to ambient $\mathrm{CO}_{2}$ treatment for all sampling days (Figure 5). Elevated $\mathrm{CO}_{2}$ resulted in an approximately $21 \%$ increase in $\mathrm{Pn}$ after 84 days of $\mathrm{CO}_{2}$ treatment. Previous studies have reported that net photosynthesis almost always increases for plants under elevated $\mathrm{CO}_{2}$ conditions, but the extent and duration of this enhancement varies with plant species and interacting environmental conditions. ${ }^{36,37}$ The enhanced photosynthesis of plants under elevated $\mathrm{CO}_{2}$ is likely due to an abundance or high availability of $\mathrm{CO}_{2}$ as a substrate for carboxylation but may also be related to the activation state of Rubisco for carbon fixation. ${ }^{38}$ Whether the stimulation of photosynthesis in creeping bentgrass is related to those factors deserves further investigation in future studies.

The water use rate from leaves was evaluated as the stomatal conductance (gs) and transpiration rate (T). The leaf $\mathrm{T}$ and gs were both reduced by $40 \%$ due to the elevated $\mathrm{CO}_{2}$ treatment (Figures $6 \mathrm{a}$ and $6 \mathrm{~b}$, respectively). During all sampling days, the plants under elevated $\mathrm{CO}_{2}$ maintained more than $30 \%$ greater WUE, expressed as the ratio of $\mathrm{Pn} / \mathrm{T}$, compared to plants under

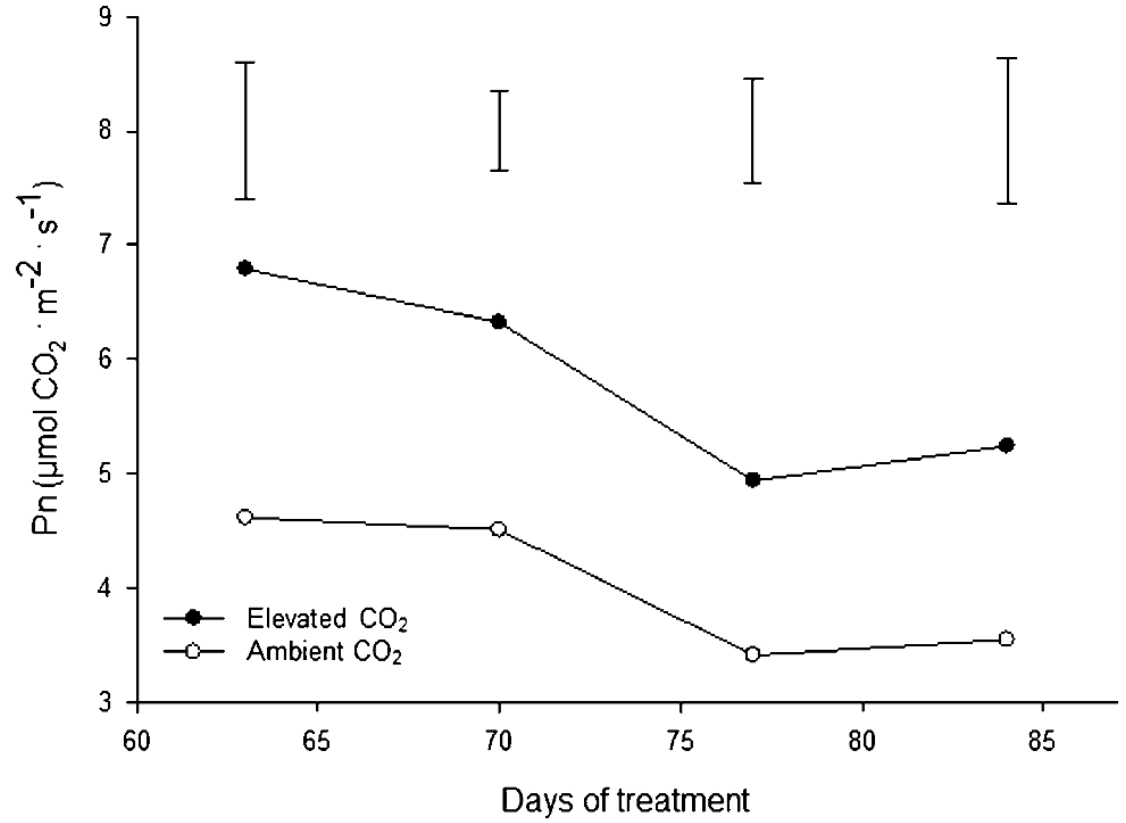

Figure 5. Net photosynthetic rates at $63,70,77$ and 84 days of elevated carbon dioxide treatment. Vertical bars indicate LSD values ( $p \leqslant 0.05)$ for comparison between treatments on a given day where significant differences were detected. 
ambient $\mathrm{CO}_{2}$ (Figure $6 \mathrm{c}$ ). The improved WUE by elevated $\mathrm{CO}_{2}$ in this study was due to the $\mathrm{CO}_{2}$ stimulation of $\mathrm{Pn}$ and $\mathrm{CO}_{2}$ inhibition of $\mathrm{T}$. Similar results with regard to all three parameters were reported for the flag leaves of winter wheat (Triticum aestivum) plants grown at elevated levels of $\mathrm{CO}_{2}{ }^{39}$ Stomatal conductance was reduced by $60 \%$ and $75 \%$ for amaranth (Amaranthus hypochondriacus) and
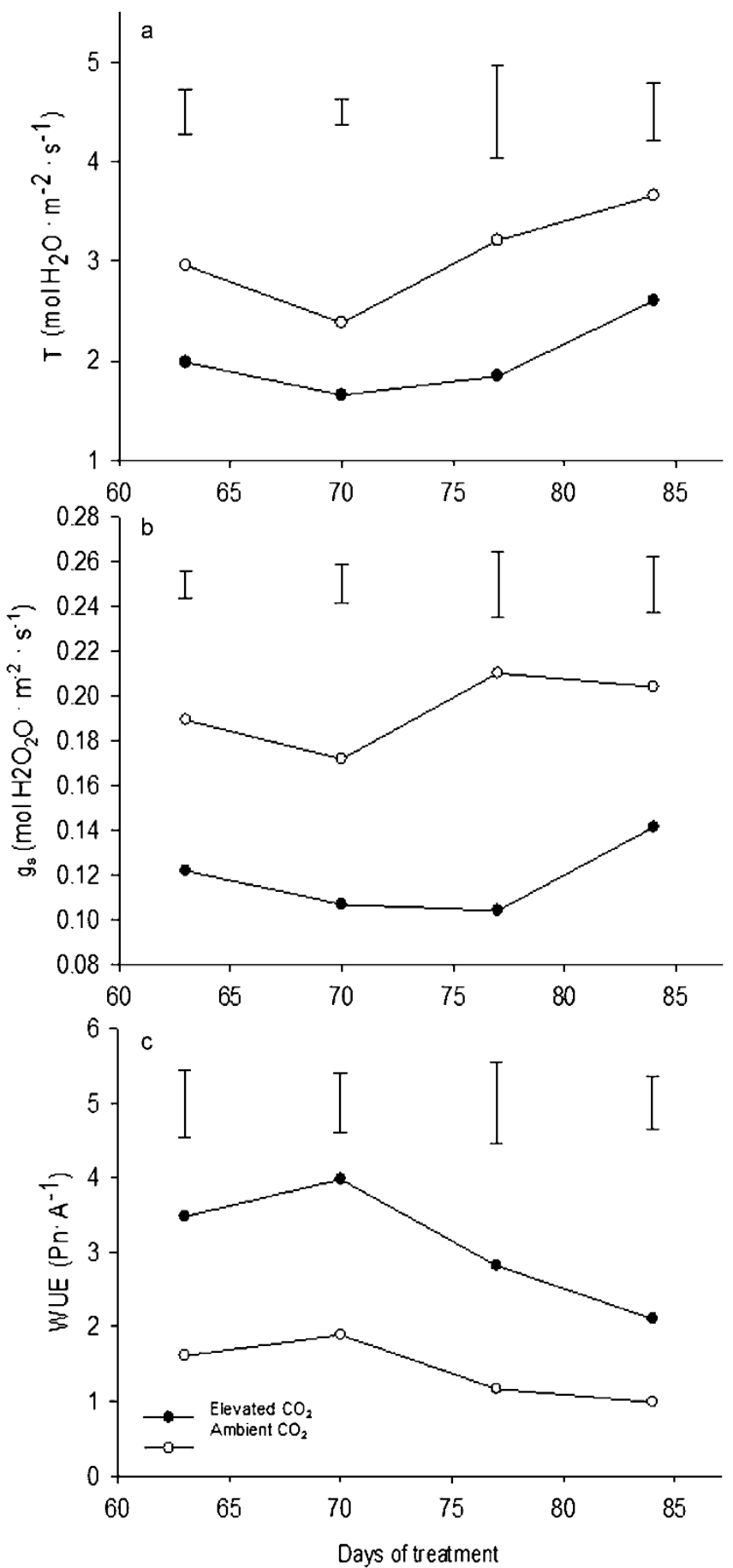

Figure 6. Leaf transpiration rates (a), stomatal conductances (b) and water use efficiencies (c) at 63, 70, 77 and 84 days of elevated carbon dioxide treatment. Vertical bars indicate LSD values $(p \leqslant 0.05)$ for comparison between treatments on a given day where significant differences were detected. soybean (Glycine max), respectively, when the $\mathrm{CO}_{2}$ levels were doubled. ${ }^{40} \mathrm{~A}$ literature review showed that the water use efficiency almost always increases for agronomic crop species grown under elevated $\mathrm{CO}_{2}$ conditions. ${ }^{41}$ Specifically regarding a cool-season grass species, doubling the $\mathrm{CO}_{2}$ level resulted in a two-fold increase in the water use efficiency of perennial ryegrass (Lolium perenne ${ }^{42}$ and corroborates the observed increase in water use efficiency of creeping bentgrass in the current study. As previously mentioned, lower amounts of water loss from leaves may lower the irrigation requirements of turfgrass, which is particularly important in areas with limited water availability for irrigation.

Transpiration through the stomates is controlled by the stomatal density and stomatal conductance. ${ }^{19}$ The stomatal density was greatly increased for creeping bentgrass grown under elevated $\mathrm{CO}_{2}$ conditions from 63 to 84 days of treatment (Figure 7a). On average, there was a $39 \%$ increase in the stomatal density; plants grown in elevated $\mathrm{CO}_{2}$ had 128 stomates per $\mathrm{cm}^{2}$, while plants under ambient conditions had 78 stomates per $\mathrm{cm}^{2}$ (Figure $7 \mathrm{~b}$ ). Several studies have also reported small changes to the stomatal density through changes in the total leaf area in response to elevated $\mathrm{CO}_{2}{ }^{43,44}$ The increase in stomatal density may facilitate the observed promotion of photosynthesis by providing more entry points for $\mathrm{CO}_{2}$ diffusion within less leaf area. However, there was an inverse relationship between the stomatal density and transpiration rate under elevated $\mathrm{CO}_{2}$ in this study as the transpiration rate was lowered under elevated $\mathrm{CO}_{2}$ despite the higher number of stomates. Given that stomatal conductance is highly correlated with the transpiration rate, it can be inferred that $\mathrm{CO}_{2}$-induced stomatal closure is a controlling factor for the reduced transpiration rate in creeping bentgrass exposed to elevated $\mathrm{CO}_{2}$ levels.

In summary, creeping bentgrass plants grown under elevated $\mathrm{CO}_{2}$ conditions displayed changes in their growth rate, leaf and root morphology, and water use that are favorable for turfgrass growth and highly desirable for turfgrass management. Specifically, the $\mathrm{CO}_{2}$ stimulation of lateral spread and production of smaller and thicker leaves, as well as increased root growth, is critically important for rapid turfgrass establishment from seeds or sprigs. Improved water use efficiency by elevated $\mathrm{CO}_{2}$ will have a significant impact on water use and may lead to changes in the irrigation management of turfgrass. Future research may address the underlying mechanisms of growth promotion by elevated $\mathrm{CO}_{2}$, such as changes in hormone metabolism.

\section{CONFLICTS OF INTEREST}

The authors declare no conflicts of interest.

\section{ACKNOWLEDGMENTS}

This research was supported by the Rutgers Center for Turfgrass Science and the New Jersey Agricultural Experiment Station at Rutgers University.

\section{REFERENCES}

1 Dlugokencky EJ. Carbon dioxide [in "State of the Climate in 2008"]. Bull Am Meteorol Soc 2009; 90: S34-S35.

2 Houghton JT, Ding Y, Griggs DJ et al. IPCC, 2001: Climate Change 2001: The Scientific Basis, Intergovernmental Panel on Climate Change. Cambridge and New York: Cambridge University Press, 2001.

3 Kirkham MB. Elevated Carbon Dioxide, Impacts on Soil and Plant Water Relations. Boca Raton, FL: CRC Press, 2011.

4 Wand SJE, Midgley GF, Jones MH et al. Responses of wild C3 and C4 grasses (Poaceae) species to elevated atmospheric $\mathrm{CO}_{2}$ conditions: a meta-analytic test of current theories and perceptions. Global Change Biol 1999; 5: 723-741.

5 Morison Jl. Stomatal response to increased $\mathrm{CO}_{2}$ concentration. J Exp Bot 1998; 49(Special Issue): 443-452.

6 Lee TD, Barrott SH, Reich PB. Photosynthetic responses of 13 grassland species across 11 years of free-air $\mathrm{CO}_{2}$ enrichment is modest, consistent and independent of N supply. Global Change Biol 2011; 17: 2893-2904. 


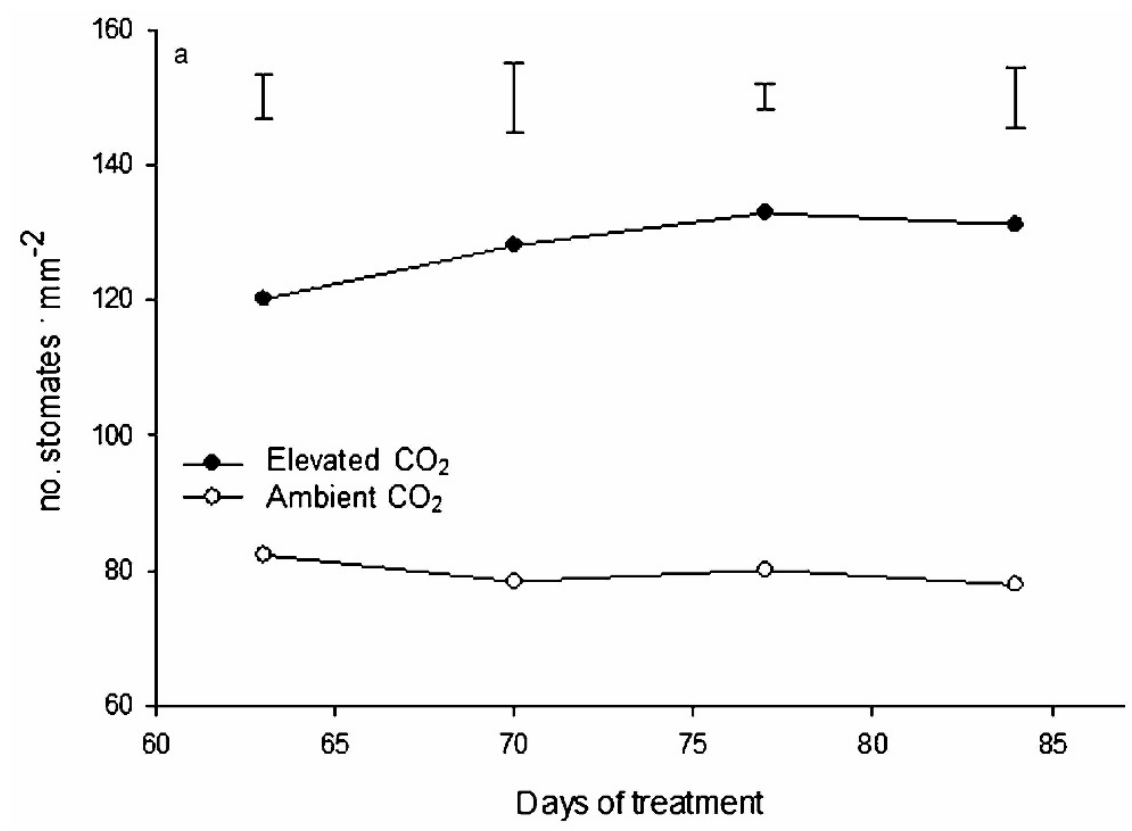

b

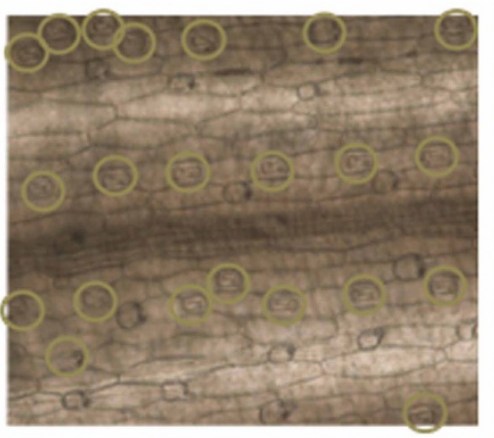

Elevated $\mathrm{CO}_{2}$

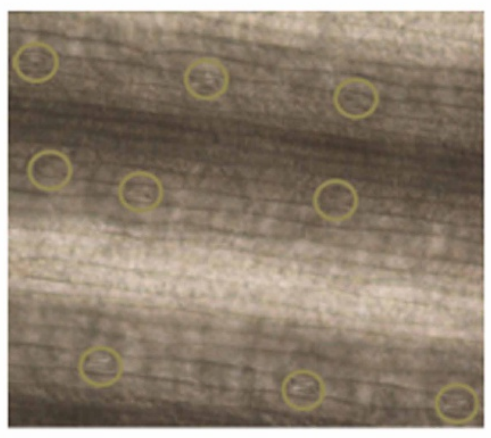

Ambient $\mathrm{CO}_{2}$

Figure 7. Stomatal densities (a) at $63,70,77$ and 84 days of elevated carbon dioxide treatment. Vertical bars indicate LSD values ( $p \leqslant 0.05)$ for comparison between treatments on a given day where significant differences were detected. Photos (b) of creeping bentgrass stomates at 84 days of treatment with elevated or ambient $\mathrm{CO}_{2}$ concentrations.

7 Reddy AR, Rasineni GK, Raghavendra AS. The impact of global elevated $\mathrm{CO}_{2}$ concentration on photosynthesis and plant productivity. Curr Sci 2010; 99: 46-57.

8 Pritchard S, Rogers $\mathrm{H}$, Prior SA et al. Elevated $\mathrm{CO}_{2}$ and plant structure: a review. Global Change Biol 1999; 5: 807-837.

9 Taylor G, Ranasinghe S, Bosac $\mathrm{C}$ et al. Elevated $\mathrm{CO}_{2}$ and plant growth: cellular mechanisms and responses of whole plants. J Exp Bot 1994; 45(Special Issue) 1761-1774.

$10 \mathrm{Yu} \mathrm{JJ}, \mathrm{Chen} \mathrm{LH}$, Xu M et al. Effects of elevated $\mathrm{CO}_{2}$ on physiological responses of Tall Fescue to elevated temperature, drought stress, and the combined stresses. Crop Sci 2012; 52: 1848-1858.

$11 \mathrm{Yu} \mathrm{J}, \mathrm{Du} \mathrm{H}, \mathrm{Xu} \mathrm{M}$ et al. Metabolic responses to heat stress under elevated atmospheric $\mathrm{CO}_{2}$ concentration in a cool-season grass species. $J$ Am Soc Hort Sci 2012; 137: 221-228.

12 Yu J, Yang Z, Jespersen D et al. Photosynthesis and protein metabolism associated with elevated $\mathrm{CO}_{2}$-mitigation of heat stress damages in tall fescue. Environ Exp Bot 2014; 99: 75-85.

13 Milesi C, Running SW, Elvidge CD et al. Mapping and modeling the biogeochemical cycling of turfgrasses in the United States. Environ Manage 2005; 36 : 426-438.

14 Beard JB, Green RL. The role of turfgrasses in environmental protection and their benefits to humans. J Environ Qual 1994; 23: 452-460.

15 Stier JC, Horgan BP, Bonos SA (eds.). Turfgrass: Biology, Use, and Management Agronomy Monograph Number 56. Madison, WI: American Society of Agronomy, 2013.
16 Vickers A. Water Use and Conservation. Amherst, MA: Water Plow Press, 2001.

17 Hoagland DR, Arnon DI. The water-culture method for growing plants without soil. Calif. Agric Exp Station Circ 1950; 347: 1-32.

18 Turgeon AJ. Turfgrass Management. 8th ed. Upper Saddle River, NJ and Columbus, $\mathrm{OH}$ : Pearson Prentice Hall, 2008.

19 Taiz L, Zeiger E. Plant Physiology. 5th ed. Sunderland, MA: Sinauer Associates Inc., 2010.

20 Hoffmann WA, Franco AC, Moreira MZ et al. Specific leaf area explains differences in leaf traits between congeneric savanna and forest trees. Funct Ecol 2005; 19: 932-940.

21 Fry J, Huang B. Applied Turfgrass Science and Physiology. Hoboken, NJ: John Wiley \& Sons, 2004.

22 Radoglou KM, Jarvis PG. Effects of $\mathrm{CO}_{2}$ enrichment on four poplar clones. I. Growth and leaf anatomy. Ann Bot 1990b65: 617-626.

23 Giuliani R, Koteyeva N, Voznesenskaya E et al. Coordination of leaf photosynthesis, transpiration, and structural traits in rice and wild relatives (genus Oryza). Plant Physiol 2013; 162: 1632-1651.

24 Kimball BA. Carbon dioxide and agricultural yield: an assemblage and analysis of 430 prior observations. Agron J 1983; 75: 779-788.

25 Ainsworth EA, Long SP. What have we learned from 15 years of free-air $\mathrm{CO}_{2}$ enrichment (FACE)? A meta-analytic review of the responses of photosynthesis, canopy properties and plant production to rising $\mathrm{CO}_{2}$. New Phytol 1980; 165: 351-372.

26 Baxter R, Ashenden TW, Sparks TH et al. Effects of elevated carbon dioxide on three montane grass species. I. Growth and dry matter partitioning. J Exp Bot 1994; 45: 305-315. 
27 Beard JB. Turfgrass: Science and Culture. Englewood Cliffs, NJ: Prentice Hall, 1973.

28 Owensby CE, Coyne PI, Ham LM et al. Biomass production in a tallgrass prairie ecosystem exposed to ambient and elevated $\mathrm{CO}_{2}$. Ecol Appl 1993; 3: 644-653.

29 Fitter AH, Graves JD, Wolfenden J et al. Root production and turnover and carbon budgets of two contrasting grasslands under ambient and elevated atmospheric carbon dioxide concentrations. New Phytol 1997; 197: 247-255.

30 Farrar JF, Williams ML. The effects of increased atmospheric carbon dioxide and temperature on carbon partitioning, source-sink relations and respiration. Plant Cell Environ 1991; 14: 819-830.

31 BassiriRad H, Gutschick VP, Lussenhop J. Root system adjustments: regulation of plant nutrient uptake and growth responses to elevated $\mathrm{CO}_{2}$. Oecologia 2001; 126: 305-320.

32 Rogers $\mathrm{HH}$, Runion GB, Krupa SV. Plant responses to atmospheric $\mathrm{CO}_{2}$ enrichment with emphasis on roots and the rhizosphere. Environ Pollut 1994; 83: 155-189.

33 Baker JT, Allen LH Jr., Boote KJ. Growth and yield responses of rice to carbon dioxide concentration. J Agric Sci 1990; 115: 313-320.

34 Carrow RN. Drought avoidance characteristics of diverse tall fescue cultivars. Crop Sci 1996; 36: 371-377.

35 Marcum KB, Engelke MC, Morton SJ et al. Rooting characteristics and associated drought resistance of zoysiagrasses. Agron J 1995; 87: 534-538.

36 Sage RF, Sharkey TD, Seemann JR. Acclimation of photosynthesis to elevated $\mathrm{CO}_{2}$ in five C3 species. Plant Physiol 1989; 89: 590-596.

37 Ainsworth EA, Davey PA, Bernacchi CJ et al. A meta-analysis of elevated $\left[\mathrm{CO}_{2}\right]$ effects on soybean (Glycine max) physiology, growth and yield. Global Change Biol 2002; 8: 695-709.
38 Habash DZ, Paul MJ, Parry MA et al. Increased capacity for photosynthesis in wheat grown at elevated $\mathrm{CO}_{2}$ : the relationship between electron transport and carbon metabolism. Planta 1995; 197: 482-489.

39 Tuba Z, Szente K, Koch J. Response of photosynthesis, stomatal conductance,water use efficiency and production to long-term elevated $\mathrm{CO}_{2}$ in winter wheat. J Plant Physiol 1994; 144: 661-668.

40 Bunce JA. Effects of doubled atmospheric carbon dioxide concentration on the responses of assimilation and conductance to humidity. Plant Cell Environ 1993; 16: 189-197.

41 Allen LH Jr, Jones $\mathrm{P}$, Jones JW. Rising atmospheric $\mathrm{CO}_{2}$ and evapotranspiration. In: Advances in Evapotranspiration: Proceedings of the National Conference on Advances in Evapotranspiration. St Joseph, MI: ASAE, 1985: 13-27.

42 Nijs I, Impens I, Behaeghe T. Effects of long-term elevated $\mathrm{CO}_{2}$ concentration on Lolium perenne and Trifolium repens canopies in the course of a terminal drought stress period. Can J Bot 1989; 67: 2720-2725.

43 Radoglou KM, Jarvis PG. Effects of $\mathrm{CO}_{2}$ enrichment on four poplar clones. II. Leaf surface properties. Ann Bot 1990; 65: 627-632.

44 Estiarte $\mathrm{M}$, Penuelas J, Kimball BA et al. Elevated $\mathrm{CO}_{2}$ effects on stomatal density of wheat and sour orange trees. J Exp Bot 1994; 45: 1665-1668.

cc) (i) $\Theta$ This work is licensed under a Creative Commons Attributioncc. NonCommercial-NoDerivative Works 3.0 License. To view a copy of this license, visit http://creativecommons.org/licenses/by-nc-nd/3.0/ 